\title{
The Saprophytic and Pathogenic Microflora from Local Tomato Cultivars Seeds
}

\author{
Gyöngyi SZABÓ, Raluca MICLEA, Maria APAHIDEAN, Carmen PUIA* \\ Faculty of Agriculture, University of Agricultural Sciences and Veterinary Medicine Cluj- Napoca, \\ Romania \\ *Corresponding author: carmen.puia@yahoo.com \\ Bulletin USAMV series Agriculture 72(2)/2015 \\ Print ISSN 1843-5246; Electronic ISSN 1843-5386 \\ DOI 10.15835/buasvmcn-agr: 11739
}

\begin{abstract}
The quality of the local population of tomato seeds has a significant role in obtaining of healthy plants and tomato fruits of superior quality. In this paper it was monitored the quality of the tomato seeds using the blotted paper method and also by the identification of the pathogenic and saprofitic mycroflora from the surface of the seeds. The highest frequency was recorded by the pathogen Cladosporium fulvum.
\end{abstract}

Keywords: Alternaria, Cladosporium, local populations, seeds, tomato.

\section{INTRODUCTION}

The local tomato cultivars named also local population or traditional varieties are characterized by the fact that they are naturally improved from a generation to another, having the capacity to tolerate hard environmental conditions with a high and constant efficiency without needing chemical input. The quality of the seeds has a great role in the success of a vegetables culture (Hoza Gheorghița, 2011). The main pathogens that can affect the quality of the tomato seeds are: Alternaria solani, Corynebacterium michiganensis, Didymella lycopersici, Fusarium oxysporum, Phytophtora infestans, Xanthomonas vesicatoria (Agarwal and Sinclair, 1996). Some pathogens such as Sclerotinia sclerotiorum are transmitted with the seeds and can remain in soil a large period of time in a saprophytic state of resistance (sclerotia) after that it can germinate and infect the plants. Also the seeds can be contaminated by saprophytes: Aspergillus sp., Rhizopus sp., Penicillium sp., Alternaria sp. (Raicu Cristina and Doina Baciu, 1978).

\section{AIMS AND OBJECTIVES}

The main purpose of this research was the monitoring of the quality of tomato seeds by determination of the germination and also by the identification of the pathogenic and saprophytic microflora of the seeds.

\section{MATERIALS AND METHODS}

The biological material used in the experiment was represented by the seeds of three local populations of tomatoes: Hostáti, Roz și Inimă de bou. The research method for the monitoring of the seeds microflora was the test on blotting paper (Raicu Cristina and Doina Baciu, 1978). The germination energy was determined after five days and after 14 days also the germination capacity. The phytosanitary observations were made with the stereomicroscope and optic microscope after five days.

\section{RESULTS AND DISCUSSION}

On the seeds of the three local tomato cultivars were identified Cladosporium fulvum, Alternaria sp. and Aspergillus niger (Fig.1). 

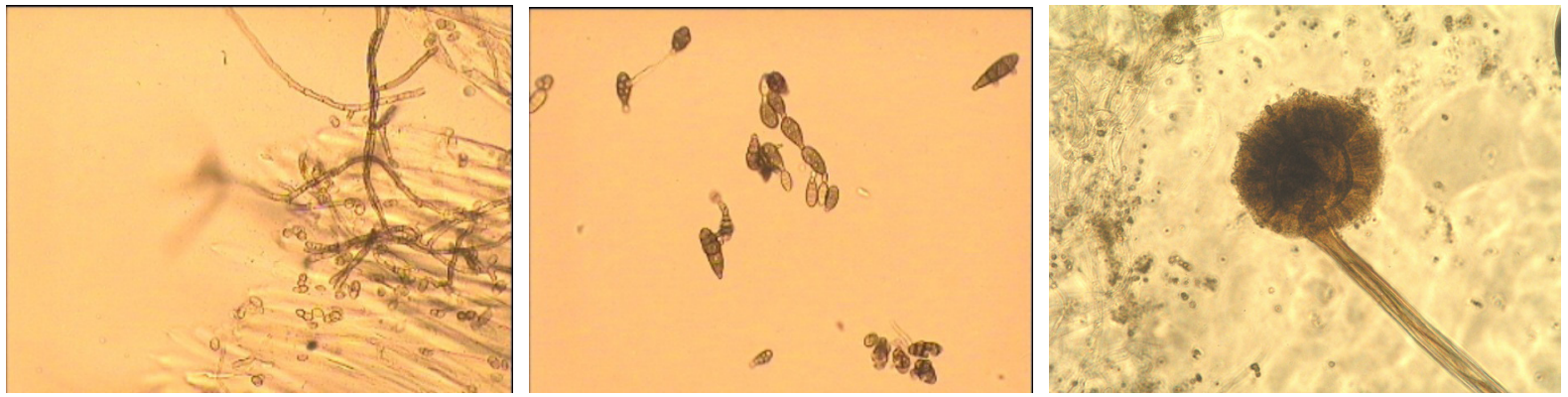

Fig.1. Cladosporium fulvum, Alternaria sp., Aspergillus niger

Tab. 1. Fungi developed on the tomato seeds

\begin{tabular}{cccc}
\hline Variety & Cladosporium fulvum \% & Alternaria sp. \% & Aspergillus niger \% \\
\hline Inimă de bou & 16.66 & 3.33 & 3.33 \\
\hline Hostáti & 6.66 & 3.33 & 3.33 \\
\hline Roz & 16.66 & 10 & \\
\hline
\end{tabular}

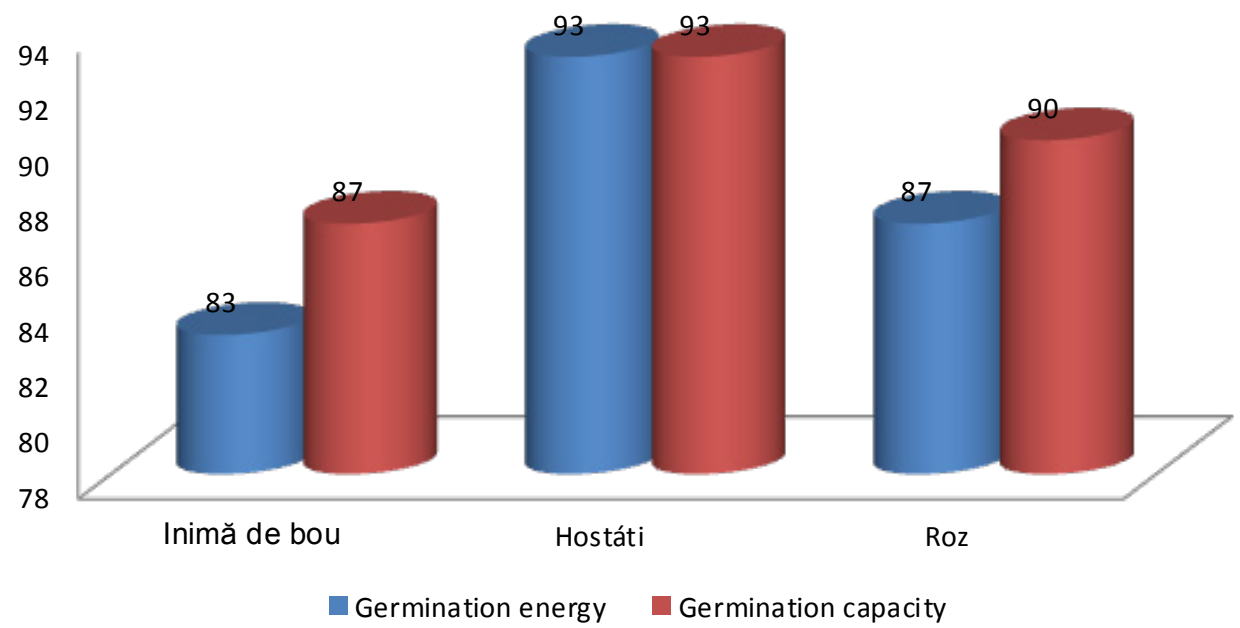

Fig. 2. The germination of the seeds

Analyzing the seeds of Inimă de bou variety the highest frequency had the pathogen Cladosporium fulvum with a percent of $16.66 \%$ followed by Aspergillus niger with $3.33 \%$. Also on the others two varieties, Hostáti and Roz the highest frequency was recorded by Cladosporium fulvum with a percent of $6,66 \%$ respective $16,66 \%$ and in the case of the last variety the pathogen Alternaria sp. had a high frequency of $10 \%$ (Tab. 1).

The Hostati variety had the highest germination percent of $93 \%$ (Fig. 2), folowed by the Roz variety with a value of $90 \%$ and the lowest germination percent was reached by Inimă de bou variety $(87 \%)$

\section{CONCLUSION}

On the seeds of the local populations of tomato taken under study were identified Cladosporium fulvum, Alternaria sp. and Aspergillus niger. As a conclusion it can be said that the seeds of the local cultivars must be disinfected before sowing.

\section{REFERENCES}

1. Agarwal VK, Sinclair JB (1996). Principles of Seed Pathology, Agriculture Plant Science.

2. Hoza G (2011). Legumicultură generală, București.

3. Raicu C, Baciu D (1978). Patologia seminței, Ed. Ceres, București. 